\title{
THE SiXTH DEVELOPMENT CABINET ANNOUNCED MARCH 17, 1993
}

\author{
The Editors
}

The Sixth Development Cabinet announced last March reveals some interesting developments now taking place in the top echelons of the New Order State. Gone, more or less, are two groups of officers/officials who have been around in the top state positions since the early years of the New Order: old soldiers (Sudomo, Soepardjo Roestam, Rudini, L. B. "Benny" Moerdani, Ismail Saleh, and Bustanil Arifin) and "technocrats" (Radius Prawiro, J. B. Sumarlin, Arifin Siregar, and Emil Salim). In their stead have come two new groups, AMN "professionals" (Gen. Edi Sudradjat, Lt. Gen. Ida Bagus Sudjana, and Maj. Gen. T. B. "Benny" Silalahi) and "engineers" (B. J. Habibie, Satrio Budihardjo Joedono, Haryanto Dhanutirto, and Wardiman Djojonegoro).

The downfall of "technocrats," or economists to be more precise, can also be seen in developments other than their numbers. First, the post of Coordinating Minister for Economic, Financial, Industry, and Development Supervision was divided into two: Coordinating Minister for Economy, Finance, and Development Supervision (Saleh Afiff) and Coordinating Minister for Industry and Trade (Hartarto). Second, "technocrats" lost two key positions: Chairman of the National Development Planning Agency (Bappenas) and Minister of Finance. This, however, does not necessarily mean that they lost out to "engineers." As the rise of Mar'ie Muhammad to Minister of Finance suggests, it may simply mean that the wave of "cadrization" which has been well established in departments such as forestry, agriculture, and public works has finally reached the department of finance. But this does mean that in industry and trade B. J. Habibie and his allies will dominate and that Saleh Afiff, one of two remaining protégés of Widjojo Nitisastro, is likely to have little say either institutionally or financially in their industrial policy making.

On the security front, Gen. Edi Sudradjat, Armed Forces Commander-in-Chief and Minister of Defense and Security as well as (until April 6) Army Chief of Staff, appeared to emerge as the new military strongman, replacing L. B. Moerdani (most of whose allies have now gone except perhaps Bakin Chief Maj. Gen. Soedibyo). A surprise in this connection is the appointment of Lt. Gen. Ida Bagus Sudjana, Edi's AMN classmate, as Minister of Mining and Energy. Because of tight budgetary constraints, since the mid-1980s soldiers' pay, housing, and other welfare conditions, as well as their weapons and equipment, have been in a 
sorry state. One wonders whether there might have been a tacit deal between Suharto and Edi, whereby ABRI would support the election of Soeharto as President for the sixth time, in return for more opportunities for the informal fund raising crucial to "professionalize" and discipline the military organization.

Below is a list of members of the new cabinet, supplemented by biographical data we have been able to gather from a variety of published and unpublished sources.

\section{Coordinating Ministers}

1. Coordinating Minister for Economy, Finance, and Development Supervision Prof. Dr. Saleh Afiff. Has been State Minister for National Development Planning as well as Chairman of the National Development Planning Agency (Bappenas) in the Fifth Development Cabinet (1988-1993). Was born in Cirebon on October 31, 1930, and graduated from the University of Indonesia's Faculty of Economics in 1959. Went on to acquire an MBA in California in 1961, and a doctorate in Agricultural Economics from the University of Oregon in 1967. Served as Deputy for Economic Affairs to the Chairman of Bappenas (Widjojo Nitisastro) from 1973-1983; Assistant to Coordinating Minister for Economics, Finance, Industry, and Development Control (Widjojo again) from 1978-1983; State Minister for Reform of the State Apparatus and Deputy Chairman of Bappenas in the Fourth Development Cabinet (1983-1988).

2. Coordinating Minister for Industry and Trade Ir. Hartarto. Has been Minister of Industry since the Fourth Development Cabinet. Was born in Delanggu, Surakarta, on May 30, 1932. Studied chemistry at the Bandung Institute of Technology, went on to study chemical engineering at the University of New South Wales, Australia, under the Colombo Plan, and graduated B.Sc. Honours in 1959. Served as Director of PN Letjes; Director of BPU Pulp \& Kertas; Director of Upbuilding in the Directorate General of the Chemical Industry; Director of the Fertilizer Industry in the Directorate General of the Chemical Industry; Director General for the Basic Chemical Industry, Department of Industry.

3. Coordinating Minister for Political and Security Affairs Lt. Gen. (Retired) Soesilo Soedarman. Has been Minister of Tourism, Post, and Telecommunications in the Fifth Development Cabinet. Was born in Maos, Cilacap, on November 10, 1928. Graduated from Yogya Military Academy, Class 1, in 1948. Attended the Breda School of Cavalry Reserve, the Netherlands, in 1952; Associate Armor Officer Advanced School, USA, in 1957; Waenaya Akademia M.W. Frunze, Moscow, in 1965; Army Staff and Command School (military attaché course) in 1967; Senior International Defense Management Course, USA, in 1976. Served as Instructor at the Yogya Military Academy as well as Operations Officer, SubWehrkreise 104, Yogyakarta, 1948/49, and Assistant-1, Bureau of Training, Ministry of Defense, 1950/51. Was attached to Bureau II, Joint Staff, Armed Forces Staff, 1951/52, and to SUAD II, Army Headquarters, 1952/53. Worked as Inspectorate Officer, Cavalry, 1953/54; on the staff at Bureau of Education, Cavalry Training Center, 1954/55; Instructor, SSKAD, 1955/56; Chief of Section II (Operations), Cavalry Headquarters, 1956-1958; Commander, Cavalry School, 1958/59; Commander, Cavalry Sqd. Battalions I/II/III, Kodam VI/Siliwangi, 1958-1960; Head of Tactical Department, Cavalry Headquarters, 1960/61; Commander, Military Academy Cadets' Regiment 1965-1967; Deputy Governor of Akabri 1968-1970; Defense Attaché in Washington D.C., 1970-1973; Head of G-3 (Personnel), Department of Defense and Security, 1973-1975; Assistant for Personnel and Manpower Development, Department of Defense and Security, 1975-1978; Commander-General, Akabri, 1978-1980; Commander, Kowilhan I (Sumatra and West Kalimantan), 1980-1985; Ambassador to the 
US 1985-1988. Was a member of Tim Sebelas (Team of Eleven) appointed by Suharto for the smooth running of the 1993 MPR session.

4. Coordinating Minister for People's Welfare Azwar Anas. Has been Minister of Transportation in the Fifth Development Cabinet. Was born in Mata Air, Padang Belakang, West Sumatra, on August 2, 1931. Graduated from the Bandung Institute of Technology with chemistry major in 1959 and attended Top Management Course at New York City University in 1975, and Urban Development Program at Paris University. Has also had considerable military education at the Cimahi military training center in 1960; Army Officer Candidate School (Secapa TNI-AD) 1967/68; and Army Staff and Command School (Seskoad) 1972/73. Served as Director-in-Chief of PT Semen Padang (1982) and Governor of West Sumatra.

\section{Ministers}

1. Minister of Interior Lt. Gen. (Retired) Raden Moh. Yogie Soewardi Memet. Has been Governor of West Java since 1985. Was born in Cirebon on May 16, 1929. Member of Tentara Pelajar Batalyon 400 (1945/46), graduated from Pusat Pendidikan Perwira AD (P3AD) in 1952 and from Army Staff and Command School (Seskoad) in 1970. Served as Deputy Commander, Battalion 330/Kujang I/Para (attached both to Kodam VI and Kostrad) (19621964); Commander, Battalion 330/Kujang I (1964-1967); Commander, Kodim (Military District Command) 0618 City of Bandung (1967/68); Chief of Staff, Brigade 17 Airborne/ Kujang, Kostrad (1969/70); Commander, Brigade 17, Kodam VI (1970-1973); Deputy Commander, Kopassandha (Army Paratroop Command, now Kopassus, Special Forces Command) (1973/74); Commander, Kopassandha (1975-1983) and Commander, Kodam VI/Siliwangi (1978-1983); Commander, Second Regional Command (Jawa, Madura, Nusatenggara) (1983-1985). Was chairman of regional representatives' fraction at the 1993 MPR and a member of Tim Sebelas (Team of Eleven).

2. Minister of Foreign Affairs Ali Alatas S.H. Minister of Foreign Affairs since the Fifth Development Cabinet (1988-1993). Was born in Jakarta on November 4, 1932, of Arab descent. Graduated from the Foreign Affairs Academy in 1954 and from the University of Indonesia's Faculty of Law in 1956. Worked at PIA news service 1952-1954. After joining the Department of Foreign Affairs, worked at the Directorate of International Economy, 1954-1956; Indonesian Embassy in Bangkok as second and then first secretary, 1956-1960. Served as Head, Directorate of Information and Cultural Relations, 1964-1966; MinisterCounselor at the Indonesian Embassy in Washington, 1966-1976; Ambassador in Geneva; Secretary to the Vice President in 1978; and Ambassador to the United Nations.

3. Minister of Defense and Security Gen. Edi Sudradjat. Serving simultaneously as Armed Forces Commander-in-Chief (since February 19, 1993) and (from February 22, 1988 until April 6, 1993) Army Chief of Staff. Sundanese born in Jambi on April 22, 1938, graduated from AMN in 1960 as the best cadet, from Army Staff and Command School (Seskoad) in 1972, and from National Defense Institute (Lemhannas), the 13th regular course, in 1980. Along with Feisal Tanjung (Armed Forces Chief of General Staff) and Kentot Harseno (Commander, Kodam Jaya), belongs to the first batch of AMN graduates who attended RPKAD training. Served as Platoon Commander, 515th Infantry Battalion, Kodam VIII, in Jember, 1961-1963; AMN instructor in 1963; Company Commander, Battalion I RPKAD, in 1964; Deputy Commander, Group I Kopassandha, in 1968; Deputy Assistant-1 (Intelligence), Kopassandha, 1971-1973; Commander, Infantry Training Center in Bandung, 1975-1978; Chief of Staff, East Timor Task Force, Department of Defense and Security, 1978/79; 
Commander, Airborne Battle Command (Kopur Linud), Kostrad, 1980/81; Commander, Kodam II, 1981-1983; Commander, Kodam VI, 1983-1985; Assistant for Operations to Armed Forces Chief of General Staff, April 1985 to June 1986; Deputy Army Chief of Staff from June 1986 to February 1988. When a major at the Army Staff and Command School, was chosen as one of 75 junior field grade officers to take part in the army seminar on the heritage of the ' 45 Generation's values. In the wake of the Dili massacre, was instructed by Supreme Commander of the Armed Forces Suharto to form a Military Honor Council to investigate the killings. Was a member of Tim Sebelas for the 1993 MPR.

4. Minister of Justice H. Oetojo Oesman S.H. Has been Chairman of BP-7 Pusat (Pancasila Propagation Agency) since 1987. Born in Jakarta on June 3, 1935, graduated from University of Indonesia's Faculty of Law and Social Studies in 1960. Worked as general manager of State Corporation (PN) Aduma Niaga, 1960-1968, while becoming a DPR member in 1967. Served as Director General of Manpower Relations, Department of Manpower, 1975-1983; Director General of Manpower Guidance and Surveillance, Department of Manpower, 1983/84 (under Sudomo); and Deputy Head of BP-7 Pusat, 1984-1987 (under Sarwo Edhie Wibowo). In the 1993 MPR, chaired Commission B which discussed issues not related to the Broad Outline of State Policy (GBHN). Has been Chairman of DPP Golkar since 1982 and Deputy Chairman of DPP SOKSI.

5. Minister of Information Harmoko. Has been Minister of Information since the Fourth Development Cabinet (1983-1988). Was born in Kertosono, Nganjuk, East Java on February 7 , 1939. Has a high school education, but considerable journalistic experience. Started working as a reporter in 1960, and after 1965 headed the editorial office of Pos Kota, the lurid newspaper originally sponsored by the Greater Jakarta Municipality regime of Ali Sadikin. After 1970, became a leading figure in the Indonesian Journalists' Association, first at the Jakarta branch level, later at the national level. Was a member of Tim Sebelas for the 1993 MPR.

6. Minister of Finance Drs. Mar'ie Muhammad. Has been Director General of Taxes, Department of Finance. Of Arab descent he was born in Surabaya on April 3, 1939. Was an HMI activist in the student movement in 1966. Studied accounting and graduated from the University of Indonesia in 1969. A career finance bureaucrat, joined the Department of Finance in 1970. Worked at Directorate General of State Financial Control, 1970-1973 and Directorate General for Monetary Affairs, 1973-1979. Served as Director for State Corporations and Limited Liability Companies, 1979-1987 and Director for State Corporations Upbuilding, both at Directorate General for Monetary Affairs.

7. Minister of Trade Prof. Dr. Satrio Budihardjo Joedono. An ally of B. J. Habibie, has been Assistant VI for Industry, Mining, and Energy to Coordinating Minister for Economics, Finance, Industry, and Development Supervision since 1988. Was born in Pangkal Pinang, Bangka, on December 1, 1940, and graduated from University of Indonesia's Faculty of Economics in 1963. Obtained an MA at the University of Pittsburg and PhD at State University of New York at Albany in 1971. Has been Professor of Economics (public administration, management, and organizational theory) at the University of Indonesia and member of National Research Council.

8. Minister of Industry Ir. Tunky Ariwibowo. Has been Junior Minister of Industry. Was born in Malang on March 13, 1936, majored in metallurgy at the Bandung Institute of Technology, and graduated from Nova Scotia Technical College, Halifax, Nova Scotia, Canada in 1960. Joined the Department of Industry in 1960 and served as Head of Asahan Aluminum Project, 1962-1964; Head of Cilegon Trikora Steel Mill Project, 1964-1967; on the Staff to the 
Minister of Industry, 1967-1972; and Director, Directorate General of Metal and Machinery, 1972-1975. Has been Director-in-Chief of Krakatau Steel since 1975.

9. Minister of Agriculture Prof. Dr. Ir. Sjarifudin Baharsjah. Has been Junior Minister of Agriculture. Born in Sindanglaut, West Java, on May 6, 1933. Obtained MSc at the University of Kentucky in 1965 and PhD at North Carolina State University in 1973. Has taught at the Bogor Institute of Agriculture and was promoted to professor in 1984. Served as Secretary General, Department of Agriculture, 1983-1988.

10. Minister of Mining and Energy Lt. Gen. (Retired) Ida Bagus Sudjana. Has been Secretary General, Department of Defense and Security, since 1988. Born in Denpasar on October 20, 1936, is the first Balinese minister under the New Order. A classmate of Edi Sudradjat, he graduated from AMN in 1960 and from National Defense Institute (Lemhannas) in 1981. Obtained MBA at Lembaga Pendidikan "Jayakarta" in 1991. Served as Training Officer, Field Artillery Training Center, 1961-1966; Deputy Commander, 9th Field Artillery Battalion in 1967; Commander, Second Field Artillery Regiment, Kostrad, 1975-1977; Commander, Korem 121 Sintang, West Kalimantan, 1978-1981; Chief of Staff, Kostrad, 1981/82; Commander, Kodam XII/Tanjungpura (West Kalimantan), 1982-1984; Assistant for Territorial Affairs to Army Chief of Staff, October 1984 to October 1985; Assistant for Social and Political Affairs to Armed Forces Chief of General Staff from October 1985 to January 1987; Armed Forces Chief of General Staff from January 1987 to January 1988.

11. Minister of Forestry Ir. Djamaloedin Soeryohadikoesoemo. Has been Director General of Forestry Exploitation, Department of Forestry. Born in Lumajang on October 11, 1934, as the son of Madurese father and Javanese mother, graduated from Gadjah Mada University in 1961 with forestry major. Served as Section Head for Planning, Perum Perhutani, in Yogyakarta (1962); Administrator of Perum Perhutani in Cepu (1966); Director of Marketing, Perum Perhutani (1973); Director of Forestry Production Upbuilding, Ministry of Forestry (1981); Director-in-Chief of PT Inhutani II (1983).

12. Minister of Public Works Ir. Radinal Moochtar. Has been Minister of Public Works since the Fifth Development Cabinet. Born in Surabaya on September 20, 1930, graduated from the Bandung Institute of Technology in 1960. Joined the Department of Public Works in 1960, and worked as Head, Directorate for Urban and Regional Planning, Department of Public Works, and in Bappenas between 1964 and 1973. Served as Director-in-Chief of Perum Perumnas (Public Housing Corporation), 1974-1978; Director General of Cipta Karya, 1978-1983; Secretary General of the Department of Public Works, 1983-1988.

13. Minister of Transportation Dr. Haryanto Dhanutirto. A long-time associate of B. J. Habibie, has been Deputy Chairman for Assessment and Application of Basic Sciences, Agency for Assessment and Application of Technology (BPPT). Was born in Purwokerto on August 14, 1939 and graduated from the Bandung Institute of Technology with pharmacy major in 1966. Studied medicinal chemistry and obtained a doctorate at Univ. Montpellier I (Fac. de Pharmacie) in 1981. Was an instructor at the Bandung Institute of Technology, 1962-1971 and became BPPT senior researcher, 1983-1987, and assistant to State Minister for Research and Technology (B.J. Habibie), 1986/87. Served as Chief of Staff, Resimen Mahawarman, 1964-1966 and DPR member, 1971-1982. Has been Deputy Secretary of Fraksi Karya Pembangunan at the MPR (1992-1997), member of MPR Badan Pekerja (1992-1997), fourth assistant to General Chairman of ICMI. Was a founder of Yayasan Pondok Pesantren Al Kamal.

14. Minister of Tourism, Post, and Telecommunication Joop Ave. Has been Director General of Tourism, Department of Tourism, Post, and Telecommunication. Born in Yogyakarta 
on December 5, 1934. Graduated from the Foreign Affairs Academy in 1957 and studied at the University of the Philippines. Briefly worked as French language program officer and announcer at Radio RI in 1957, and joined the Department of Foreign Affairs in the same year. Served as Consul General in New York in 1967 and Chief of Protocol at the Presidential Palace from 1972 to 1978 . Has Dutch, English, German, and French.

15. Minister of Cooperatives and Small Business Development Drs. Subiakto Tjakrawerdaya. Born in Cilacap on August 10,1944, has been Director General for Job Creation of Cooperatives, Department of Cooperatives, since September 1987. Graduated from Indonesian Christian University's Faculty of Economics with business economics major and from National Defense Institute (Lemhannas) in 1985 as one of the three best. Worked in private business from 1972 to 1978 , and then became expert staff to Junior Minister of Cooperatives, as well as Head, Unit for Management, Upbuilding, and Development of Village Unit Cooperatives (KUD), Directorate General for Job Creation of Cooperatives, 1978-1983.

16. Minister of Manpower Drs. Abdul Latief. Was born in Banda Aceh on April 27, 1940 and is Director-in-Chief of PT Pasaraya Nusakarya (the Sarinah Jaya group). Graduated from the Indonesian Business Leadership Academy, Department of Industry, in 1963 and attended department store management course of the Seibu Group in Tokyo in 1965.

Worked at PT Department Store Indonesia Sarinah 1963-1971 and became its Director-inChief in 1971. Served as Director, Indonesian Business Leadership Academy, Department of Industry, 1969/70. Was founder and first General Chairman of Young Businessmen's Association of Indonesia (HIPMI), 1972/73, and has been Chairman of its Honorary Council since 1975. Served as Chairman for Trade and Cooperatives, Indonesian Chamber of Commerce (Kadin), 1979-1982.

17. Minister of Transmigration Ir. Siswono Yudohusodo. Previously State Minister of Public Housing in the Fifth Development Cabinet. Was born in Long Iram, East Kalimantan, on July 4, 1943. Graduated from the Bandung Institute of Technology with civil engineering major in 1967. Served as Chairman of Indonesian Real Estate, 1983-1988; Deputy Chairman of Indonesian Chamber of Commerce, 1987/88; Chairman, Department of Cooperatives and Private Business, Golkar, 1983-1988; and Chairman of Young Businessmen's Association of Indonesia (HIPMI), 1972-1976.

18. Minister of Education and Culture Dr. Ing. Wardiman Djojonegoro. A long-time associate of B.J. Habibie since his Aachen days, has been Deputy for Administration, Agency for Technological Assessment and Application (BPPT). Madurese priyayi born in Pamekasan on June 22, 1934, majored in shipbuilding at the Bandung Institute of Technology, 1953-1955, went on to study at Delft Institute of Technology, 1955-1958, and graduated from Aachen Institute of Technology, Germany, in 1962. Obtained a doctorate from Delft Institute of Technology in 1985. Worked as credit analyst at Indonesia Development Bank (Bapindo), 1963-1966 and served as Head, Bureau for Administration, Jakarta Municipality Government, 1966-1979. Joined BPPT in 1979 as Assistant to Minister for Research and Technology (B.J. Habibie). Has been Secretary General of Japan-Indonesia Science and Technology Forum since 1985; Secretary of ICMI (Indonesian Muslim Intellectuals' Association) since its foundation in 1990; and Commissioner-in-Chief of Yayasan Abdi Bangsa which publishes Republika. Served as Rector of Indonesian Institute of Technology, 1987-1989, and as Chairman and Coordinator of the Human Resources Development Project, funded by the World Bank and Japan's OECF, has sent approximately 2,500 students for study abroad.

19. Minister of Health Prof. Dr. Sujudi. Has been Rector of the University of Indonesia since 1986. Born in Bogor on September 9, 1930, was educated at Taman Siswa school in 
Bogor. Graduated from University of Indonesia's Medical School in 1959. Studied briefly at the Department of Medical Microbiology, Stanford University, 1956/57, and acquired a doctorate in 1972 from the University of Indonesia's Medical School. Has been a professor at the University of Indonesia since 1972. Served as Head of Microbiology, University of Indonesia's Medical School, 1966-1979; Assistant Dean of the University of Indonesia's Medical School, 1974-1977; Assistant Rector, University of Indonesia, 1977-1981. Has been Chairman, Research Institute, University of Indonesia, since 1983; Chairman of Indonesian Microbiology Association since 1981; and Chairman for Education, Yayasan Al Azhar, since 1983.

20. Minister of Religion Vice Admiral (Retired) Dr. Tarmizi Taher. Has been Secretary General, Department of Religion, since 1987. Was born in Padang on October 7, 1936. Joined the Navy in 1959 as a navy cadet. Graduated from the University of Airlangga's Medical School in Surabaya in 1963 when a navy captain. Attended On-the-Job Training Course, US Navy, in San Diego; Medical Study for Senior Officers Course, US Navy, in Washington; and Strategic Management Course in Pittsburgh in 1991. Served as navy medical officer, 1964-1977; Head of Navy Mental Upbuilding Service in 1979; Deputy Head of Armed Forces' Mental Upbuilding Center, 1980-1982; and Head of Armed Forces' Mental Upbuilding Center, 1982-1987. Has been an instructor at Staff and Command Schools and Lemhannas since 1984.

21. Minister of Social Affairs Dra. Endang Kusuma Inten Soewena. Married Lt. Gen. (Retired) Soeweno, former Commander of Kostrad (1983-1986), when Soeweno was a RPKAD battalion commander in 1967. Was born in Tulungagung, East Java, on February 2, 1945, the daughter of Brig. Gen. (Retired) Kusen Hirohoesodo, an army doctor. Was educated at the University of Diponegoro's Medical School. Has been a DPR member (Golkar) since 1987 and is Secretary General of Himpunan Wanita Karya 1991-1996.

\section{State Ministers}

1. Minister/State Secretary Drs. Moerdiono. Has been State Secretary/State Minister since the Fifth Development Cabinet. Was born in Banyuwangi on August 19, 1934. Graduated from the Ministry of Interior's Public Administration Academy (Akademi Pemerintahan Dalam Negeri, APDN) in 1957. A long-time associate of former Vice President Sudharmono since the start of the New Order, served as Cabinet Secretary in the Third Development Cabinet and as Junior Minister and Cabinet Secretary in the Fourth Development Cabinet. Was a member of Tim Sebelas for the 1993 MPR.

2. Minister/Cabinet Secretary Drs. Saadillah Mursjid. Has been Junior Minister/Cabinet Secretary in the Fifth Development Cabinet. Was born in Barabai, South Kalimantan, on September 7, 1937. Graduated from Gadjah Mada University in 1964, studied at the Rotterdam School of Economics, the Netherlands, and obtained an MBA at Harvard University. Joined Bappenas (National Development Planning Agency) in 1965 and served as Deputy for Spiritual Affairs (Deputi bidang Spiritual dan Rohaniah), Bappenas.

\section{Minister of National Development Planning/Chairman of National Development} Planning (Bappenas) Vice Marshal Ir. Drs. Ginandjar Kartasasmita. Has been Minister of Mining and Energy in the Fifth Development Cabinet. Born in Bandung on April 9, 1941, was educated at the elite Catholic Canisius High School of Jakarta (1953-1959), the Bandung Institute of Technology (1959/60), and Faculty of Agriculture, University of Tokyo (19601965). Between 1970 and 1980 attended also the School of Public Administration and received an MA. Has also had considerable military education, including Basic Officer 
Training (1966/67), and attending the Air Force's Sekolah Siasat in 1968, and its Staff and Command School in 1974. On his return from Tokyo in 1965, worked for KOTI's Gabungan $V$ under Achmadi, and then in the Air Force's Directorate for Research and Development. Between 1968 and 1971 was head of the Research Section of the State Secretariat's Bureau for Development Analysis. A long-time associate of former Vice President Sudharmono, became head of the Evaluation Section of the Cabinet Secretariat's Bureau for Foreign Technical Cooperation, assistant to the Cabinet Secretary for State Administrative Affairs (1976-1978), assistant to the Minister/State Secretary in charge of state administrative affairs and administrative matters relating to non-departmental state agencies (1978-1983), Junior Minister for Promoting the Utilization of Domestically Manufactured Products (PPPDN), and Chairman of the Investment Planning Coordination Board. Since 1977 has been a member of the board of commissioners of PT Nurtanio (now PT Industri Nusantara). Chaired Commission A which discussed the Broad Outlines of State Policy at the 1993 MPR.

4. Minister for Research and Technology/Chairman of Agency for Technological Assessment and Application (BPPT)/Head of Agency for Strategic Industries (BPIS) Prof. Dr. Ing. Bacharudin Jusuf ("Rudy") Habibie. Has been State Minister for Research and Technology and Chairman of BPPT since the Third Development Cabinet (1978-1983). Son of Bugis-Makassarese father and Yogyanese priyayi mother, was born in Pare Pare, South Sulawesi, on June 25, 1936. Was educated at the Bandung Institute of Technology (1954/55) and graduated from the Aachen Institute of Technology (department of aeronautic light engineering), Germany, in 1960. Then worked as special scientist at Hamburger Flugzeubau (1965/66), Department Head of Structure Analysis, MBB (Messerschmitt-Boelkow-Blohm), Germany, from 1966 to 1973. Served as advanced technology and aeronautics adviser to the President, adviser to the Director-in-Chief of Pertamina (Ibnu Sutowo), and Head of Pertamina's Advanced Technology and Aeronautics (1974 to 1976); Chairman of Indonesian Aeronautics and Space Institute (LAPAN) (1983-1991); and Chairman, Council for Strategic Industries (1983-1989). Has been Director-in-Chief of Nusantara Aircraft Industry (IPTN) since 1976; Chairman of Batam Industrial Development Authority since 1978; Director-inChief of PT PAL (shipbuilding) since 1978; Director-in-Chief of PT PINDAD (army's weapons production) since 1983; and Chairman, Agency for Strategic Industries (BPIS) since 1989. Has also been Chairman of Indonesian Muslim Intellectuals' Association (ICMI) since its foundation in 1990. Was a member of Tim Sebelas for the 1993 MPR.

5. Minister for Food Production/Chairman of National Logistics Board (Bulog) Prof. Dr. Ibrahim Hasan. Has been Governor of Aceh. Was born the son of an Acehnese ulama in Lampoh Weng, Pidie, on March 16, 1935. Graduated from University of Indonesia's Faculty of Economics in 1960, obtained an MBA at Syracuse University, and acquired a PhD at the University of the Philippines in 1979. Served as Deputy for Storage and Distribution, Bulog (1982-1986); Rector of Syiah Kuala University, Banda Aceh; and Chairman of Aceh Regional Development Planning Board, before being appointed Governor of Aceh in 1987. Was a member of Tim Sebelas for the 1993 MPR.

\section{State Minister for Population/Chairman of National Family Planning Board (BKKBN)}

Dr. H. Haryono Suyono. Was born in Pacitan, East Java, on May 6, 1938, the son of an elementary school teacher. Graduated from the Academy of Statistics in 1963. Obtained a doctorate in communications at the University of Chicago in 1972. Worked as UN expert assistant for industrial statistics; aide to Prof. Widjojo Nitisastro in formulating the first Five-Year Development Plan; Deputy Bureau Chief of Population, Central Bureau of Statistics (BPS); Research Coordinator for reporting, BKKBN; and Deputy Chairman of BKKBN. Has been Chairman of National Planning Coordinating Board since 1983. 
7. Minister for Investment/Chairman of Investment Planning Coordination Board (BKPM) Sanyoto Sastrawardoyo M.Sc. A Javanese priyayi born in Purwokerto on May 31, 1936, studied at the Bandung Institute of Technology from 1955 to 1958 and obtained a master of engineering degree at Syracuse University in 1962. Joined the Department of Industry and worked as Section Head for Testing and Application of Technical Production (1962-1964); Head, Material Testing, Directorate of Aircraft Industry (1975-1979); Secretary, Directorate General of Basic Metal Industry (1979-1983); Director for Standardization and Evaluation, Directorate General of Basic Metal Industry. Then was transferred to State Secretariat and worked as Secretary to Junior Minister in Charge of Promoting the Utilization of Domestically Manufactured Products (Ginanjar Kartasasmita), 1983/84. Served as Deputy Chairman of the Investment Coordinating Board (BKPM), 1984-1988. Has been Chairman of the Investment Coordinating Board since 1988. Served also as Chairman of the Bandung Institute of Technology's Alumni Association, 1988-1992.

8. Minister of Agrarian Affairs/Chairman of National Land Agency Ir. Soni Harsono. Has been Head of National Land Agency since the agency was created out of the Directorate General of Agrarian Affairs in 1983. Studied shipbuilding in Hanover, Germany, in 1961. Served as Assistant for Administrative Affairs to State Secretary (Sudharmono).

9. Minister for Public Housing Ir. Akbar Tandjung. A Mandailing Batak, born in Sibolga, Central Tapanuli, on August 14, 1945, was educated at the University of Indonesia's Faculty of Engineering (Electronics). Has been State Minister for Youth and Sport, but was often said to be Menteri Dan (Minister And) because his substantial job was stolen by Suharto's eldest daughter Mbak Toetoet.

10. Minister for Environment Ir. Sarwono Kusumaatmadja. Has been State Minister for Reform of State Apparatus in the Fifth Development Cabinet. Born in Jakarta on July 24, 1943, was educated at the Bandung Institute of Technology, active in KAMI and Chairman of the KAMI Bandung branch, $1967 / 68$. Has been a DPR member since 1971, and served as leader of Golkar Fraction in the DPR and Secretary General of Golkar.

11. Minister for Women's Roles Raden Ajeng Siti Aminah ("Mien") Sugandhi. Was born in Magelang on October 8, 1934, the daughter of R.M. Soeprapto Djojokoesoemo (who once served as Deputy Chief of Police) and R.A. Siti Chotimah. Graduated from the Academy of Foreign Languages in 1975 and married the late Maj. Gen. R. H. Sugandhi Kartosubroto, former aide to President Soekarno and Deputy Chairman of the DPA (Supreme Deliberative Council). Was active in the Secretariat of Persit and served as Secretary General of Ikatan Kesejahteraan Keluarga Hankam (IKKH). Is a DPR/MPR member, Chairman of Kowani (Korp Wanita Indonesia, Indonesian Women's Corps), Chairman of DPP Golkar, Chairman of DPP Himpunan Wanita Karya, Chairman of DPP HKTI (Himpunan Kerukunan Tani Indonesia), and General Chairman of DPP MKGR (Wanita Musyawarah Kekeluargaan dan Gotong Royong). Brig. Gen. Soeyono, former adjutant to President Suharto and now Chief of Staff, Kodam 2/Sriwijaya, is her son-in-law.

12. Minister for Youth and Sports Hayono Isman. Was born on April 23, 1955, the second son of the late Maj. Gen. Mas Isman, founder of the Kosgoro Business Group. Is the youngest minister ever in the history of New Order. Studied at but did not graduate from New Hampshire College. Head of the Kosgoro Business Group, is Director-in-Chief of PT Elmi Perdana and Director and Commissioner of the Kosgoro group companies. Served as Treasurer of Indonesian Oil and Gas Drilling Association in 1986 and General Chairman, Indonesian Young Businessmen's Cooperatives in 1988. Has been a leading member of the 
Forum of Communication for Retired ABRI Officers' Children (Forum Komunikasi PutraPutra Purnawirawan ABRI). Has been a DPR member since 1992.

13. Minister for Reform of State Apparatus Maj. Gen. Tiopan Bernhard ("Benny")

Silalahi. Has been Secretary General, Department of Mining and Energy, since 1988. A Toba Batak born in Pematang Siantar on April 17, 1938, studied briefly at the Bandung Institute of Technology in 1957, but graduated from AMN in 1961. Was educated also at the University of Pajajaran's Faculty of Law. Known as a leading military intellectual, graduated from Army Staff and Command School (Seskoad) in 1972, Armed Forces Staff and Command School (Seskogab) in 1976, and National Defense Institute (Lemhannas), always as the best. Attended International Defense Management Course in Monterey and Peace Keeping Trainng Course in Vienna, Austria. Served as Commander, Cavalry Battalion 8 Tank/Kostrad (1972); Camp Commandant, UN Emergency Force in Cairo (1973); Instructor, Seskoad (1974-1978); Assistant for Operations to Chief of Staff, Kodam XIV/Hasanuddin (1978); Chief of Staff, Kodam 4/Diponegoro from May 1985 to March 1986 (under Harsudiyono Hartas), Fifth Assistant (Research and Development/Planning and Budgeting) to Army Chief of Staff from March 1986 to September 1988 (under Try Sutrisno and Edi Sudradjat). Has been Chairman of Yayasan Kartika Eka Paksi, army fund-raising arm, and has served in that capacity as Commissioner-in-Chief of PT Tambang Timah, PT International Timber Corporation Indonesia, PT Dana Yasa Arthatama, and Bank Artha Graha.

$* * * * *$

On the same level with ministers:

1. Governor of Bank Indonesia Dr. J. Sudradjat Djiwandono. Has been Junior Minister of Trade in the Fifth Development Cabinet. Born in Yogyakarta on August 17, 1938, obtained $\mathrm{PhD}$ at Boston University in 1980 with economics major. Served as Head, Economic Research Institute, LIPI (1968/69); Assistant to Minister of Trade (1969-1972); Bureau Head for Monetary and State Finance Affairs, Bappenas; and Assistant for Monetary, Balance of Payment, and State Finance Affairs to Coordinating Minister for Economy, Finance, Industry, and Development Supervision.

2. Commander-in-Chief of the Armed Forces Gen. Edi Sudradjat.

\section{Attorney General Singgih S.H.}

